\title{
Amino Acids and Amines Stimulate Gastrin Release from Canine Antral G-Cells via Different Pathways
}

\author{
John DelValle and Tadataka Yamada \\ Department of Internal Medicine, The University of Michigan Medical Center, Ann Arbor, Michigan 48109
}

\begin{abstract}
The major determinant of meal-stimulated gastric acid secretion is the antral hormone gastrin. Decarboxylated amine derivatives of amino acids have been proposed as the final common mediators of gastrin secretion stimulated by a meal. We explored the cellular basis for this hypothesis using a recently developed isolated canine G-cell model. Both amino acids and, more potently, their corresponding amines, directly stimulated gastrin release. Amino acid-stimulated gastrin secretion was unaffected by decarboxylase inhibitors (alpha methyldopa, aminooxyacetic acid, and 4-deoxypyridoxine) but enhanced by bombesin, isobutylmethylxanthine, and dibutyryl cAMP. Somatostatin inhibited amino acid-stimulated gastrin release via a pertussis toxin-sensitive GTP-binding protein. In contrast, gastrin secretion induced by amines was unaltered by any of the various treatments. Our data indicate that amino acids and amines, either as primary constituents of an ingested meal or as metabolites of dietary proteins, act directly via separate mechanisms to stimulate gastrin secretion from G-cells. (J. Clin. Invest. 1990. 85:139-143.) amines • amino acids • G-cells
\end{abstract}

\section{Introduction}

The major determinant of meal-stimulated gastric acid secretion is the antral hormone gastrin $(1,2)$. The mechanisms by which food in the stomach influences gastrin secretion are unknown, but proteins and their breakdown products appear to be the primary stimulants $(3,4)$. Indeed, studies by Lichtenberger et al. (5) have suggested that the decarboxylated amine derivatives of amino acids may be the final common mediators of meal-stimulated gastrin secretion. Generally these studies have been conducted in vivo or in whole organ preparation, thus they have not permitted determination of the direct vs. indirect actions of nutrients. Recently we developed a model for study of G-cells isolated from the gastric antrum (6). In the present experiments we applied this model in an effort to elucidate the cellular basis for nutrient-stimulated gastrin secretion.

Address reprint requests to Dr. J. DelValle, 3912 Taubman Center, The University of Michigan Medical Center, Ann Arbor, MI 481090362.

Received for publication 28 November 1988 and in revised form 31 July 1989.

J. Clin. Invest.

(c) The American Society for Clinical Investigation, Inc.

0021-9738/90/01/0139/05 \$2.00

Volume 85, January 1990, 139-143

\section{Methods}

Materials. Somatostatin-14 and bombesin were purchased from Peninsula Laboratories, Inc. (Belmont, CA). Pertussis toxin (PT), ${ }^{1}$ gentamicin, Hepes, dibutyryl cAMP (DbcAMP), chloroquine, isobutyl methylxanthine (IMX), alpha methyldopa, aminooxyacetic acid, 4deoxypyridoxine, L-amino acids, amines, hydrocortisone, crude collagenase type I, and EDTA were purchased from Sigma Chemical Co. (St. Louis, MO). DME and Ham's F-12 medium were obtained from Irvine Scientific (Santa Ana, CA). Basal medium Eagle, Earle's balanced salt solution, and trypsin $(0.25 \%)$ /EDTA $(1 \mathrm{mM})$ were purchased from Gibco Laboratories (Grand Island, NY). Multiwell (24 $\mathrm{mm}$ ) tissue culture plates were purchased from Flow Laboratories, Inc. (McLean, VA).

Cell isolation and culture. The methods used for isolation of canine antral G-cells have been described previously (6). In brief, antral mucosa from freshly excised canine stomach was bluntly separated from submucosa, cut into small pieces (3-5 $\mathrm{mm}$ ), and dispersed by sequential incubation in collagenase $(0.35 \mathrm{mg} / \mathrm{ml}$ Basal Medium Eagle $/ 10$ $\mathrm{mM}$ Hepes/0.1\% BSA) for $15 \mathrm{~min}$, EDTA (1 mM) for $10 \mathrm{~min}$, and then collagenase $(0.35 \mathrm{mg} / \mathrm{ml})$ for $15 \mathrm{~min}$. Cells dispersed from tissue up to this point were discarded, and the tissues were subsequently treated with fresh collagenase solution for two subsequent incubations of 90 and $30 \mathrm{~min}$. The harvested cells were filtered sequentially through two grades of nylon mesh (Nos. 63 and 240; Naz-Dar/K.C., Troy, MI) and loaded onto an elutriator rotor (Beckman Instruments, Inc., Fullerton, CA). Cell separation was achieved by changing the rotor speed and the flow rate in the manner previously described (7). The elutriator fractions enriched in gastrin cells were combined and resuspended in culture medium composed of a 1:1 vol/vol mixture of DME and Ham's F-12 medium supplemented with hydrocortisone (1 $\mu \mathrm{g} / \mathrm{ml})$, gentamicin $(100 \mu \mathrm{g} / \mathrm{ml})$, and $10 \%$ heat-inactivated dog serum. Cells $\left(2.0-2.5 \times 10^{6}\right.$ cells $\left./ \mathrm{ml}\right)$ were plated onto tissue culture wells previously coated with a thin film of polymerized type I collagen prepared from rat tails, and incubated in humidified $95 \%$ air and $5 \% \mathrm{CO}_{2}$ at $37^{\circ} \mathrm{C}$.

Release studies. After $42-46$ h of culture, $\sim 25 \pm 2 \%$ of cells remaining attached to the tissue culture plates were G-cells by immunohistochemistry, virtually all of the remaining cells were periodic acidSchiff positive mucus cells or fibroblasts (6). The medium was aspirated and the cells were washed twice with $2 \mathrm{ml}$ of Earle's balanced salt solution supplemented with $0.1 \%$ BSA and $15 \mathrm{mM}$ Hepes. The cells were then incubated in $2 \mathrm{ml}$ of this buffer supplemented with various agents under study at $37^{\circ} \mathrm{C}$ for $2 \mathrm{~h}$. After incubation, a $1-\mathrm{ml}$ aliquot was collected and particulate matter was removed by centrifugation for $1 \mathrm{~min}(8,500 \mathrm{~g})$ in a microcentrifuge (Beckman Instruments, Inc.). After complete aspiration of the media, cells from eight to ten culture wells were treated with $1 \mathrm{ml}$ of trypsin $(0.25 \%) / E D T A(1 \mathrm{mM})$, boiled for 10 min centrifuged, and the supernatants were kept at $-20^{\circ} \mathrm{C}$ until assay. When examining the effects of PT, the cells were preincubated in the presence of PT $(200 \mathrm{ng} / \mathrm{ml})$ for $4 \mathrm{~h}$ before performing the release experiments.

Radioimmunoassay. Radioimmunoassay for gastrin using antisera 5135 , kindly donated by Dr. Grace Rosenquist (University of Califor-

1. Abbreviations used in this paper: DbcAMP, dibutyryl cAMP; IMX, isobutyl methylxanthine; PT, pertussis toxin. 
nia Davis, Davis, CA), was performed as previously described (8). The detection limit of this assay is $0.25 \mathrm{fmol} / \mathrm{ml}$ and half maximal inhibition of binding was achieved at a gastrin concentration of $2.5 \mathrm{fmol} / \mathrm{ml}$. Assays for gastrin released into the media and in cell extracts were performed at dilutions of 1:20-1:100 and 1:1,000, respectively. For each measurement of gastrin release in a single preparation, we used two separate culture wells, each of which was assayed in duplicate. The amount of gastrin released was expressed as a percentage of total cell content. All experiments conducted with cells from a single dog preparation were considered to constitute an $n$ of 1 . Basal release was $3.3 \pm 0.7 \%$ cell content or $147.6 \pm 9.3 \mathrm{fmol} / \mathrm{ml}(\operatorname{mean} \pm \mathrm{SE}, n=11)$. The basal level of gastrin release varied $<8 \%$ between different cell preparations.

Statistical analysis. Nonparametric $t$ test was used for the determination of significance for paired comparisons or two-way analysis of variance for comparison of a single control to multiple treatments (9).

\section{Results}

We first examined the effect of various L-amino acids and their corresponding amines on gastrin release. As depicted in Fig. 1, alanine, cysteine, phenylalanine, tryptophan, and the corresponding amines, ethylamine, cysteamine, phenylethylamine, and tryptamine at a concentration of $10^{-2} \mathrm{M}$ significantly stimulated gastrin release. The aromatic amino acids (tryptophan and phenylalanine) were more potent stimulants of gastrin release than either alanine or cysteine and the amines were consistently more potent stimulants than their corresponding amino acids.

As illustrated in Fig. 2, phenylalanine stimulated gastrin release in a dose-dependent manner. In order to enhance tryptophan's relatively weak stimulatory effect on gastrin release and permit easier analysis of the dose response curve we also performed the experiment in the presence of the phosphodiesterase inhibitor, IMX. The corresponding amine, phenylethylamine, also stimulated gastrin release in what appeared to be a dose-dependent fashion that was unaltered with the addition of IMX. Nearly identical results were obtained with tryptophan and tryptamine (data not shown).

To examine further the possibility that amino acids stimulate gastrin secretion by conversion to amines via decarboxylation, we determined the effect of various nonspecific decar-

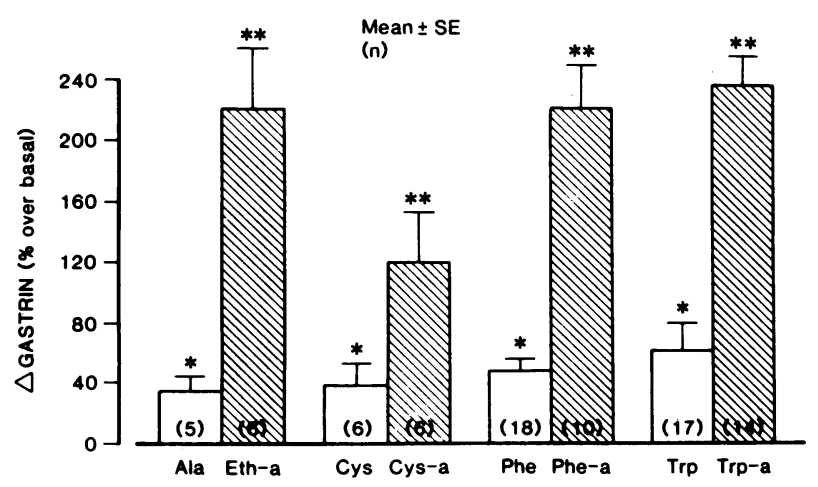

Figure 1. Effect of various amino acids $\left(10^{-2} \mathrm{M}\right)$ and their corresponding amines $\left(10^{-2} \mathrm{M}\right)$ on gastrin release from isolated canine antral G-cells. In this and subsequent figures, the number of experiments is indicated in parentheses at the bottom of each bar. Ala, alanine; Eth-a, ethylamine; Cys, cysteine; Cys-A, cysteamine; Phe, phenylalanine; Phe-a, phenylethylamine; Trp, tryptophan; Trp-a, tryptamine. ${ }^{*} P<0.05$ vs. control; ${ }^{* *} P<0.01$ vs. control.

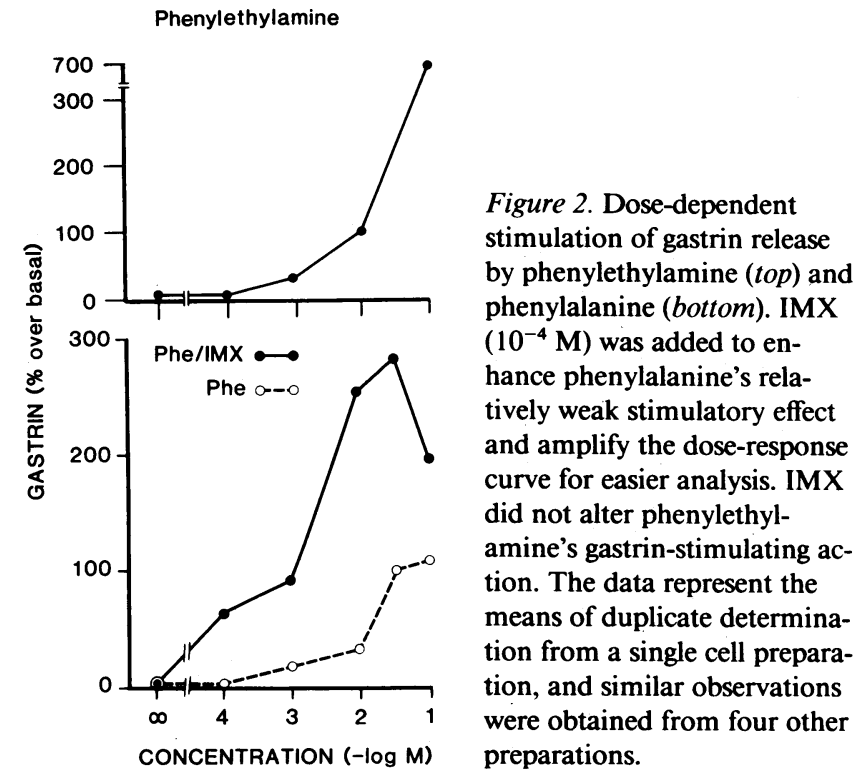

boxylase inhibitors on amino acid-mediated gastrin release. Alpha methyldopa, aminooxyacetic acid, and 4-deoxypyridoxine in concentrations from $10^{-3}$ to $10^{-8} \mathrm{M}$ failed to inhibit tryptophan- or phenylalanine-mediated gastrin release signifcantly. The results obtained using maximum concentrations of these agents are shown in Fig. 3. These findings suggest that amine formation is not the major pathway by which amino acids stimulate gastrin release.

We next examined the interaction of amino acids and amines with other known stimulants. IMX, a phosphodiesterase inhibitor, $\left(10^{-4} \mathrm{M}\right)$ and DbcAMP $\left(10^{-3} \mathrm{M}\right)$ significantly enhanced phenylalanine $\left(10^{-2} \mathrm{M}\right)$ mediated gastrin release in an additive fashion, but failed to alter the action of phenylethylamine (Fig. 4).

Bombesin is known to stimulate gastrin release via a calcium-dependent signal transduction mechanism (6); thus we examined its effect on amino acid and amine-mediated G-cell activation. As shown in Fig. 5, bombesin failed to alter phenylethylamine's action, and it exerted a less than additive effect on gastrin release when combined with phenylalanine. Similar data were obtained using tryptophan and its corresponding amine, tryptamine (data not shown).

The effect of somatostatin, a known inhibitor of gastrin release, was tested on the stimulatory action of amino acid and

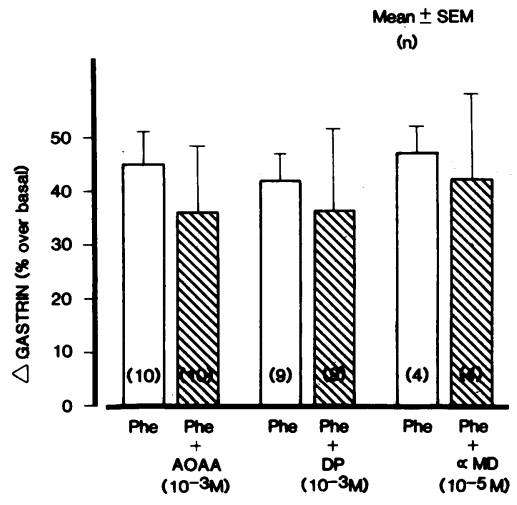

Figure 3. Effect of various decarboxylase inhibitors on phenylalanine $\left(10^{-2} \mathrm{M}\right)$ stimulated gastrin release. Phe, phenylalanine; MD, alpha methyldopa; AOAA, amino oxyacetic acid; DP, 4-deoxypyridoxine. 


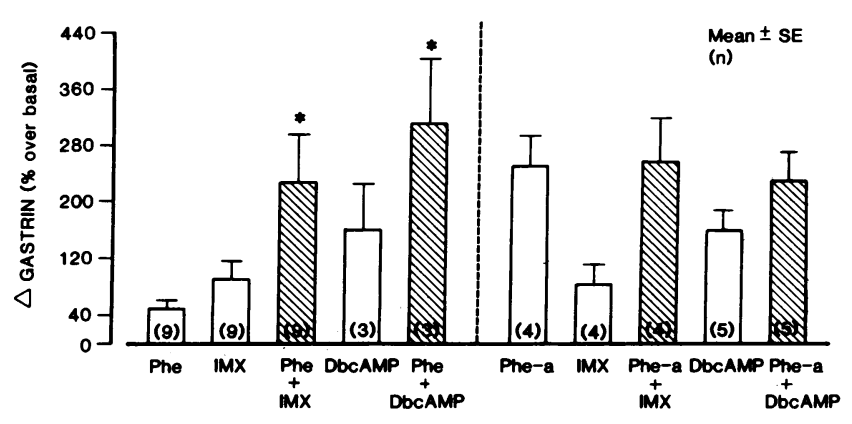

Figure 4. Effect of IMX $\left(10^{-4} \mathrm{M}\right)$ and $\operatorname{DbcAMP}\left(10^{-3} \mathrm{M}\right)$ on phenylalanine (Phe, $10^{-2} \mathrm{M}$ ) and phenylethylamine (Phe-a, $\left.10^{-2} \mathrm{M}\right)$ stimulated gastrin release. ${ }^{*} P<0.05$ vs. Phe-stimulated gastrin release.

amines (Fig. 6). Somatostatin $\left(10^{-6}-10^{-9} \mathrm{M}\right)$ significantly inhibited phenylalanine and tryptophan-mediated gastrin release, but failed to alter significantly the stimulation of gastrin induced by phenylethylamine and tryptamine.

We characterized somatostatin's inhibitory actions by examining the effects of PT, an agent known to inactivate the inhibitory guanine nucleotide-binding proteins regulating adenylate cyclase activity. As shown in Fig. 7, preincubation of G-cells with PT $(200 \mathrm{ng} / \mathrm{ml})$ reversed somatostatin's inhibitory effect on phenylalanine-stimulated gastrin release, suggesting that somatostatin acts via a PT-sensitive GTP-binding protein.

To test the hypothesis that amines might be stimulating gastrin by diffusing into G-cells and destabilizing their secretory granules by alkalinizing them, we examined the effects of another acidotropic weak base, chloroquine. At a concentration of $10^{-3} \mathrm{M}$, chloroquine significantly increased gastrin release $(168 \pm 12 \%$ of control, mean $\pm \mathrm{SE}, n=4, P<0.01$ vs. control). As in the case of the amines, somatostatin $\left(10^{-7} \mathrm{M}\right)$ failed to reverse this effect.

\section{Discussion}

Although the stimulation of gastric acid secretion by a meal can be influenced by a number of factors, including those of cephalic and intestinal origin, the major component appears to

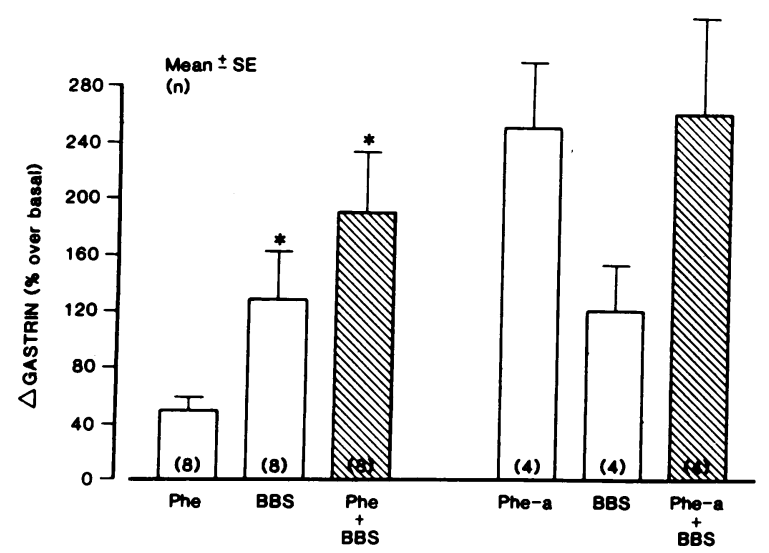

Figure 5. Effect of bombesin (BBS, $10^{-7} \mathrm{M}$ ) on phenylalanine (Phe $10^{-2} \mathrm{M}$ ) and phenylethylamine (Phe-a, $10^{-2} \mathrm{M}$ ) stimulated gastrin release. ${ }^{*} P<0.05$ vs. Phe-stimulated gastrin release.

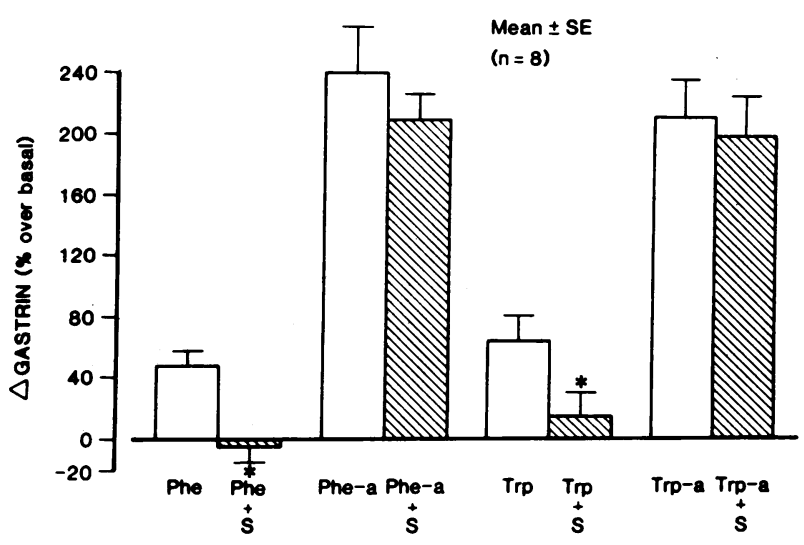

Figure 6. Somatostatin $\left(\mathrm{S}, 10^{-7} \mathrm{M}\right)$ effect on phenylalanine (Phe, $10^{-2} \mathrm{M}$ ), phenylethylamine (Phe-a, $10^{-2} \mathrm{M}$ ), tryptophan (Trp, $10^{-2}$ $\mathrm{M})$, and tryptamine (Trp-a, $\left.10^{-2} \mathrm{M}\right)$ stimulated gastrin release. ${ }^{*} P<0.01$ vs. Phe- and Trp-stimulated gastrin secretion.

derive from the interaction of food constituents with elements contained within the stomach itself (10). Previous studies $(1,2)$ have demonstrated that the majority of the acid secretory response to a meal can be ascribed to the effects of gastrin, a peptide hormone secreted by specialized endocrine cells in the gastric antrum. Since proteins are the primary food constituents found to have an acid secretagogue action, it is not surprising that only proteins are capable of significantly stimulating gastrin secretion $(11,12)$. Indeed the metabolic products of proteins, the amino acids, have been reported to be more potent gastrin stimulants than intact proteins (13), and Lichtenberger et al. $(5,14)$ have hypothesized further that amino acids must be decarboxylated to their amine-derivative forms before this agonist activity can be observed. We have used a novel preparation of isolated and enriched canine antral G-cells (6) to study the cellular basis for the action of amino acids and amines on gastrin secretion.

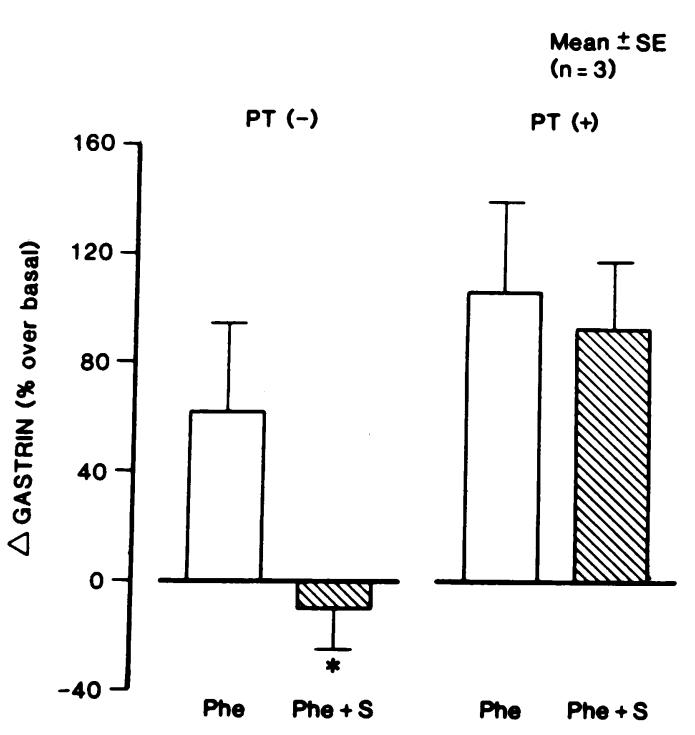

Figure 7. Influence of PT $(200 \mathrm{ng} / \mathrm{ml})$ preincubation $(4 \mathrm{~h})$ on somatostatin's $\left(\mathrm{S}, 10^{-7} \mathrm{M}\right)$ inhibitory action on phenylalanine $\left(\mathrm{Phe}, 10^{-2} \mathrm{M}\right)$ stimulated gastrin release. ${ }^{*} P<0.01$ vs. Phe-stimulated gastrin release. 
Our results demonstrate that both amino acids and their decarboxylated amine derivatives are capable of direct action on G-cells to stimulate gastrin secretion. This assertion must be tempered by the recognition that the preparation that we used consisted of only $25 \%$ G-cells, but the remainder of the constituents of the preparation were fibroblasts and mucous cells that are not likely to exert an influence on gastrin secretion. We observed further that amines are consistently more potent stimulants than amino acids. The greater stimulatory action of aromatic as opposed to aliphatic or charged amino acids is consistent with previous reports obtained in vivo (15). Although high concentrations of both amino acids and amines were required to stimulate gastrin release, such concentrations $\left(10^{-4}-10^{-2} \mathrm{M}\right)$ are known to exist in meals normally ingested by man $(16-18)$.

In contrast to the earlier reports by Lichtenberger et al. (5), the stimulatory effect of amino acids appeared to be primary and did not depend upon their decarboxylation to amines since decarboxylase inhibitors had no effect on gastrin release. Indeed, we obtained several lines of evidence that amino acids and amines used different pathways for stimulation of G-cells. Amino acids appeared to act in the manner of other receptormediated secretagogues in that their effects were dose-dependent and inhibitable with somatostatin. Moreover, the interaction of amino acids in an additive fashion with cAMP-dependent stimulants and in a less than additive fashion with $\mathrm{Ca}^{++}$-dependent stimulants of gastrin release suggests the possibility that they act via a $\mathrm{Ca}^{++}$-dependent mechanism. This hypothesis requires confirmation by direct measurements of intracellular-free $\mathrm{Ca}^{++}$concentrations in G-cells stimulated with amino acids.

In contrast to amino acids, amine-stimulated gastrin secretion was not influenced by other agents, whether stimulatory or inhibitory. These properties suggest that amines may have some nonspecific, nonreceptor-mediated action in G-cells to cause gastrin secretion. This did not appear to result from cell death or damage since no change in cell viability (as validated by exclusion of the vital dye, trypan blue) was noted with concentrations of amines as high as $0.1 \mathrm{M}$. Others have suggested that because amines are hydrophobic bases, they may diffuse into G-cells and accumulate in acidic secretory vesicles. By neutralizing the contents of the vesicles they may destabilize them and cause degranulation. The uninhibitable stimulation of gastrin that we observed with chloroquine, a substance structurally unrelated to amines but with the same acidotropic weak base properties (19), supports such a hypothesis.

It is particularly noteworthy that somatostatin could not inhibit the effect of amines. In other systems, somatostatin is capable of inhibiting release of cellular products via action at both receptor and postreceptor sites. Indeed, somatostatin has been reported to inhibit secretory events in some instances at the level of degranulation itself (20). It has been the general observation that when somatostatin is able to inhibit a particular function of a cell it does so regardless of the means of stimulation. In previous studies, for example, we have observed that gastrin release from G-cells stimulated by either cAMP or $\mathrm{Ca}^{++}$-dependent mechanisms can be inhibited by somatostatin (6). It is distinctly unusual in this setting that gastrin release by amines cannot be inhibited.

The inhibition of amino acid-stimulated gastrin secretion appears to occur via a PT-sensitive guanine nucleotide GTPbinding protein. PT is generally known to inactivate mecha- nisms mediated by guanine nucleotide-binding proteins that inhibit adenylate cyclase and cellular cAMP production (21). However, the behavior of amino acids in interacting with other stimulants of gastrin release suggests that they may act via $\mathrm{Ca}^{++}$-dependent mechanisms rather than those dependent on cAMP. Thus, in this circumstance, somatostatin may function as it does in pituitary tumor cells (22) to influence $\mathrm{Ca}^{++}$-dependent postreceptor mechanisms.

Our findings provide insight into the gastric phase of gastric acid secretion. Amino acids and amines, either as primary constituents of an ingested meal or as metabolites of dietary proteins, appear to stimulate gastrin secretion directly via separate mechanisms. The released gastrin can, in turn, account for the majority of the acid secretory response to a meal. Whatever additional effects the components of a meal may have on oxyntic cells or other gastric endocrine cells, they are likely to be of secondary importance to this primary link between nutrients and G-cells.

\section{Acknowledgments}

We are grateful to Pamela Evans for typing this manuscript.

These studies were supported by National Institutes of Health (NIH) grant R01-DK34306 and funds from the Michigan Gastrointestinal Peptide Research Center under NIH grant P30-DK34933. Dr. DelValle is a recipient of a Robert Wood Johnson Minority Faculty Development Award and an NIH Clinical Investigator Award (grant K08-DK01823).

\section{References}

1. Feldman, M., J. H. Walsh, H. C. Wong, and C. T. Richardson. 1978. Role of gastrin heptadecapeptide in the acid secretory response to amino acids in man. J. Clin. Invest. 61:308-313.

2. Blair, A. J., III, C. T. Richardson, J. H. Walsh, and M. Feldman. 1987. Variable contribution of gastrin to gastric acid secretion after a meal in humans. Gastroenterology. 92:944-949.

3. Richardson, C. T., J. H. Walsh, M. Hicks, and J. S. Fordtran. 1976. Studies on the mechanisms of food stimulated gastric acid secretion in normal human subjects. J. Clin. Invest. 58:623-631.

4. Feldman, E. J., and M. I. Grossman. 1981. Liver extract and its free amino acids equally stimulate gastric acid secretion. Am. J. Physiol. 239:G493-496.

5. Lichtenberger, L. M., R. Delansorne, and L. A. Graziani. 1982. Importance of amino acid uptake and decarboxylation in gastrin release from isolated G-cells. Nature (Lond.). 295:698-700.

6. Sugano, K., J. Park, A. H. Soll, and T. Yamada. 1987. Stimulation of gastrin release by bombesin and canine gastrin releasing peptides. Studies with isolated canine G-cells in primary culture. J. Clin. Invest. 79:935-942.

7. Yamada, T. 1989. Isolation and primary culture of endocrine cells from canine gastric mucosa. Methods Enzymol. In press.

8. Rosenquist, G. L., and J. H. Walsh. 1980. Radioimmunoassay of gastrin. In Gastrointestinal Hormones. G. B. Jerzy-Glass, editor. Raven Press, New York. 769-795.

9. Glantz, S. A. 1987. Primer of Biostatistics. B. K. Barry and J. White, editors. McGraw-Hill Inc., New York. 369 pp.

10. Feldman, M. 1983. Gastric secretion. In Gastrointestinal Disease. 3rd ed. M. H. Sleisenger and J. S. Fordtran, editors. W. B. Saunders Company, Philadelphia. 541-558.

11. Blair, E. L., J. R. Greenwell, and E. R. Grunk. 1975. Gastrin response to meals of different composition in normal subjects. Gut. 16:776-773.

12. Lichtenberger, L. M. 1982. Importance of food in the regulation of gastrin release and formation. Am. J. Physiol. 243:G429-441. 
13. Elwin, L. E. 1974. Gastric acid responses to antral application of some amino acids, peptides and isolated fractions of protein hydrolysate. Scand. J. Gastroenterol. 9:239-247.

14. Lichtenberger, L. M., L. A. Graziani, and W. D. Dubinsky. 1982. Importance of dietary amines in meal induced gastrin release. Am. J. Physiol. 243:G341-347.

15. Taylor, I. L., W. J. Byrne, D. L. Christie, M. E. Ament, and J. H. Walsh. 1982. Effect of individual L-amino acids on gastric acid secretion and serum gastrin and pancreatic polypeptide release in humans. Gastroenterology. 83:273-278.

16. Davidson, S., and R. Passmore. 1972. In Human Nutrition and Dietetics. 8th ed. Churchill-Livingstone, Inc., New York. 40-53.

17. Hegsted, D. M. 1972. Proteins. In Nutrition: A Comprehensive Treatise. G. H. Beaton and E. W. McHenry, editors. Academic Press, New York. 116-173.
18. Maga, J. A. Amines in foods. 1978. CRC Crit. Rev. Food Sci. Nutr. 10:373-403.

19. Mellman, I., R. Fuchs, and A. Helenius. 1986. Acidification of the endocytic and exocytic pathways. Annu. Rev. Biochem. 55:663700 .

20. Green, R., and D. Shields. 1984. Somatostatin discriminates, between the intracellular pathways of secretory and membrane proteins. J. Cell Biol. 99:97-104.

21. Ui, M., T. Katada, T. Murayama, H. Kurose, M. Yajima, M. Tamura, T. Nakamura, and K. Nogimori. 1984. Islet-activating protein, pertussis toxin: a specific uncoupler of receptor mediated inhibition of adenylate cyclase. Adv. Cyclic Nucleotide Protein Phosphorylation Res. 17:145-151.

22. Reisine, T. 1985. Multiple mechanisms of somatostatin inhibition of adrenocorticotropin release from mouse anterior pituitary tumor cells. Endocrinology. 116:2259-2266. 